\title{
Applying Transparency Principle on the Planning and Budgeting in Mataram
}

\author{
Hendriadi, Sahri, Prayitno Basuki \\ Economics Post Graduate Program University of Mataram \\ E-mail: hendrianakjamal@gmail.com
}

Received: March 22, 2017; Accepted: September 12, 2017; Published: November 3, 2017

Permalink/DOI: http://dx.doi.org/10.17977/um002v9i22017p122

\begin{abstract}
This study aims to discover how far the transparency principle applied in planning and conducting matters in Mataram. A qualitative approach with phenomenology design is used in this study. The data were collected by interviewing 10 people who were selected purposively, completed with observation and documented study, and the data were analyzed with interactive data analysis. The result shows that in the planning, the majority of process and stages in the application, accessibility, and availability of documents, adequacy and completeness of information, the regulation guarantying transparency and information service institution have applied transparency principle; however, the application is not yet adequate because the planning in sphere, the publication process and planning result, as well as the functionality of the Information and Documentation Management Officials (IDMO) are not applied well. Meanwhile, regarding the budgeting, in the planning, the majority of processes, accessibility and availability of documents, adequacy and completeness of information, as well as the information service institution have not yet to apply transparency principle since the budgeting discussion in a Regional House of Representative (RHR) is awfully inaccessible, have excluded the society, have no public socialization and consultation for the Draft of Budget Revenue and Expenditure/Regional Budget, and the IDMO is not yet formed in the Agency of Regional Development Field and in the Agency of Regional Finance.
\end{abstract}

Keywords: Transparency, Information, Planning, and Budgeting JEL Classification: G31, H73

\section{INTRODUCTION}

In a country that practices democracy like Indonesia, the execution of State's matters should be reported to the society. A responsible government is that which allowed the society to take part in the development of the country. The participation of the society can run smoothly if the process and outcome of the arranged policy open transparently. This is in line with what was stated by Patchurrahman et al. (2013: 28); that transparency, accountability, participation are the three most important components in good governance. Of the three pillars, transparency becomes the most influential in the country's organization. It is in line with the elaboration in article 2 clause (3) in Law Number 25 of 2004 regarding National Development Planning System (NDPS), which stated that NDPS is done based on the General Principle of Good Government. General Principle of Good Government is including the principle of openness which is a principle that opens 
oneself to the rights of society and to obtain accurate, honest, and indiscriminative information about the state organization while still considering the protection of individual rights, group, and the state confidential information. So is in the budgeting context. Budgeting as a stage in order to arrange, discuss, and determine the budgeting document, should be done transparently. Transparency is believed in contributing the low deviation of budgeting and development. Moreover, the government cannot manipulate the outcome of the planning and budgeting because of the society-involved or not - has the same information governance.

To this moment, the process of planning and budgeting refer to the same system and regulation. In planning, the process and mechanism refer to the provisions of the Law Number 25 of 2004. Meanwhile, the budgeting process refers to the provisions of the Domestic Ministry Regulation Number 13 of 2006 regarding the Regional Finance Management Manual. The process of planning and development, moreover, has been carried out in Mataram since 2002 and referred to the Regional Regulation Number 27 of 2001 regarding the Planning of Society Cooperation Conference (PSCC). One of the points arranged is planning.

The process of PSCC including PSRC of planning should be done transparently. According to Regional Regulation, article 3 clause (1), PSCC is based on the principle of participative, and oriented problem solving appropriate with the transparency and accountability in the execution of governance and development. Next, in article 5a, it was stated that one of the purposes of PSRC is to grow the response of society toward transparency and accountability in order to create a good government in Mataram. In budgeting matter, the application of transparency principle becomes the main section that contributes to increasing the quality of budgeting information processing and document.

However, based on the observation conducted by researcher toward the application of PSRC planning and budgeting in 2016 in Mataram, the transparency aspect is not yet applied well because the information related to the priority list of problem, data and potential problem map, the previous annual development, the strategic issues that should be examined, information about the number of suggestions obtained that has been realized in the previous year forum, the evaluation result of the annual development realization including the Regional Planning of Medium Term Development, and the priority list of regional development for the following year, are not distributed well to the society. In fact, the schedule, place, implementation, facilitators, and the rules of PSRC implementation are not published. In the budgeting process appeared the same case too especially the discussion of budgeting in Regional Assembly who tends to be closed off and low participation of the society.

This problem arouses anxiety regarding the function of monitoring that does not run, either by society or the related institution. This condition affects the application of transparency principle in planning and budgeting. It is interesting to investigate the application of transparency principle in planning and budgeting in Mataram. Therefore, the statement of the problem in this study is how the application of transparency principle in planning and budgeting in Mataram? Based on the statement of the problem, the aim of this study is to find out whether the quality of transparency principle application in planning and budgeting in Mataram city is run well or not. 


\section{LITERATURE REVIEW}

\section{Transparency and Information Disclosure}

Research related to transparency in regional planning and budgeting has been conducted by Syaifullah (2008) discussed the general analysis of regional development planning and emphasized on the participation aspect. Even though the transparency aspect is not examined, one finding in the study stated that the annual planning in Magelang is not yet transparent. The bureaucracy and public officials have wider access and authority in every planning step compare to other actors. A dialogue is not yet effective because the information exchange between the bureaucracy and public officials does not occur. The society has given their proposals, however, the bureaucracy and public officials have not delivered the information regarding strategic issues, policy direction, budgeting ability, Regional Working Unit (RWU) program or activity functioning as a reference to the society in expressing their proposals.

Setyawati (2010) stated that discovered the influence of council members knowledge toward the Regional Budget (RB) monitoring was not strengthened with the existence of public policy transparency, especially the announcement of budgeting policy to the public that can increase transparency, easier access to the budgeting document, and the punctually annual responsibility report. Budgeting transparency policy can indeed accommodate and increase the public suggestions, and the existence of information supply to the public can increase the budgeting transparency policy. However, conveying the budgeting to the public, easier access to the budgeting document, and the punctually annual responsibility report, do not guarantee better knowledge of the council members, especially in monitoring regional finance. This finding covered only the regional finance based on how far the council member knowledge toward the regional budget. This finding examined only the regional finance monitoring based on how deep the council comprehends the RB. This study will not examine the planning and budgeting where the RPR also holds an important role in this process. This study emphasized only in the knowledge of budgeting influence to the council members. The public involvement and the transparency of public policy are treated as a temporary variable. Martani, et al (2013) stated that the transparency of finance and performance of regional government in Indonesia is conducted in the form of information presentation.

Another research regarding the application of transparency principle was conducted by Sa'adah (2015) discovered that accountability and transparency budgeting in GBP and TPBS RB, Blitar is still unsatisfactory. This is because, First, society is not involved in the process of GBP, TPBS and RRB discussion. Second, the result of the agreement is not distributed to the public both in GBP-TPBS and RBU. Third, the response process is not published. The execution of information published in planning and budgeting has been done via electronic. However, the application is still half done, the government does not publish the result of the discussion.

Related research to regional planning and budgeting was also conducted by Ashari (2015: 156) focuses more on society participation in the annual development planning in North Lombok Regency. This study discovered that the society still thinks that the Regional Budget has not yet mirrored their needs that unsuitable with the result of Development Planning Conference. The low information obtained by the people is the cause of this. 
Generally, transparency or disclosure as the government principle is defined as the principle to open oneself toward society right to obtain accurate, honest, and indiscriminative information regarding the state organization while still considering the protection of individual rights, group rights, and the nation confidential information (Sulistoni \& Hendriadi, 2004: 147). Meanwhile, Stiglitz (1998); Zetra (2009) stated that transparency is the basic rights to know information about the current program of the government and why it is chosen to be funded. In principalagent context, the citizen as principal has the right to understand the behavior of their agent especially when the agent is the government or international organization. The same perspective was suggested by 1998 Nobel winner Amartya Sen who described the role of transparency in a marketing function. Research about famine in Bengal, Sahel, Bangladesh, and Ethiopia showed famine occurred years in those countries was caused significantly by the low information about the availability of food source compared to the low availability itself.

Whereas Maani (2009: 48) defined transparency as supplying information about administration for public and guarantying the easiness of obtaining accurate and satisfactory information. The definition explains that transparency is not only about supplying information but also about administration organization, and should provide easiness for the public to obtain that information as well. Mardiasmo in Indarto (2012: 43), transparency means the openness of the government in delivering information about the management of public resource to those who might need the information. Transparency is sharing information openly about a positive or negative organization in order to increase accountability of organization in the eye of stakeholder (Hatcher, 2003).

Meanwhile, The Law Number 14 of 2008 Regarding Public Information Disclosure emphasized that the openness of information is a significant part of transparency. Obtaining public information except in certain exceptional information according to the provision of Law in order to fulfill the rights for information (Part I. Public, The Explanation of Law Number 14 of 2008 Regarding Public Information Disclosure; 24). Based on the explanation above, it can be concluded that the immediate relation between information openness and transparency. Information openness is the concrete form of transparency.

The advantages of transparency are plenty. One of them, according to Indarto (2012: 43) in the research literature Transparency and National Government Communications, transparency makes the administration process and law formation easier to understand by the public. Whereas according to Pachurahman et al. (2013: 29) information openness is expected to result in healthy and tolerant political rivalry, and the policy is made according to the public interest. Moreover, with the application of transparency and accountability in the management of government finance, the trust and support of the public will be gained. Eventually, the government will be more serious and more discipline working the application of budget will be more participative and pro-poor, the mechanism of monitoring internally and externally will be stronger that we can be free from corruption, collusion, and nepotism. Furthermore, with the increasing of financial transparency and accountability, it is expected that the public service will be better and the good and clean administration will turn to reality (Zetra, 2009; 1).

Pope (2000: 429) also explained that various advantages can be enjoyed by every interested party if the government is open with information, like the following 
(a) Public receiving more information can take part in democracy process; (b) Parliament, press and public must follow and examine the government behavior genuinely; secrecy is a big obstacle in government responsibility, (c) Civil Servants make important decisions affecting many people, and to make sure the responsibility is done well, the government should supply complete information about what they are doing (d) the better flow of information can produce more effective administration and assists the development of even more flexible policy; (e) the cooperation between public and government will be more intimate because the supply of information is better supplied.

\section{Regional Planning and Budgeting}

Conyers and Hills (1984); Munir (2002) defined planning as an integrated process that covered decisions and alternative choices of the resources used to reach specific purpose in the future. Whereas Jhingan (2013: 518-519), gave a more concrete definition of planning, "planning is basically intentional Economic controlling and setting by the central government to reach some targets and purposes in a certain period of time". In the relation of a region, Ashari (2015: 2324) stated that (1) regional planning as a form of planning (development) that is an implementation or elaboration of central planning (national), and (2) regional planning is the outcome of regional struggling and formulation of local interest. From the definition above, regional development planning is not just a planning made by the region but in this case, planning also related to the planning with the intention of national development.

After the development planning, the next step of the government is arranging activities, discussing, and determining the budget or budgeting. Suhirman in Berek et al. (2006: 141) stated that budgeting is the process of arranging, discussing, and determining the budget to decide the medium of allocation, distribution, stabilization, and monitoring budget of public resources. Whereas Sopanah (2010: 6), Budgeting is a process of arranging the budgeting planning and expense in a period of time. Meanwhile, according to Jumarim (2007: 66) budgeting is the process of arranging, discussing and determining the budgeting document. Budgeting is the most important step in determining the regional budgeting process. In the practice, various planning and budgeting types can be found, one argumentation by Munir (2002: 41) based on the time period, planning can be divided into two; (a) long-term planning, usually has in the range between 10 to 25 years. Long-term planning is the blueprint of development that must be executed in long-term periods. (b) Medium term planning usually has the range of 4 to 6 years. In medium term planning, though it is still general but the targets in big clusters (a sectoral target) can be clearly projected. (c) Short term planning has the range of one year, commonly called annual operational planning. Of the three planning, short-term planning is the most accurate.

Meanwhile, the regional budgeting has various types. They are (1) LineItem Budgeting, (2) Incremental Budgeting, (3) Revenue Budgeting), (4) Repetitive Budgeting, (5) Supplemental Budgeting, (6) Performance Budgeting, (7) Planning Programming Budgeting System, and (8) Zero Based Budgeting (cited in Syarifudin, 2003: 6-9). Currently, the regional budgeting system in Indonesia uses performance budgeting approach. This system has been applied in Indonesia since 2005 and still used massively and effectively until now. With this method, the 
budgeting is arranged based on the performance that can be measured in every activity. However, this method used classification based on the object, such as lineitem budgeting. The determinant in this method is the efficiency from various activities using cost standard.

\section{The Regional Planning and Budgeting Process}

The Planning and Budgeting process is the whole step of planning, discussing and determining done based on the regional budgeting cycle. Practically, according to Anggarini and Puranto (2010: 61) development planning is carried out through four stage: (b) Determining the Planning, (c) Controlling the planning application, and (d) Evaluating the planning application. Technically, according to the Law number 25 of 2004 regarding the National Development Planning System, the development planning processes are: (1) The Arrangement of Regional Long-Term Development Planning, (2) The Arrangement of Regional Medium Term Development Planning, (3) The Arrangement of Regional Annual Development Planning containing the first program of The Government Regional Work plan, Preparing the work plan of the Regional Work Unit Coordination in the arrangement of Regional Working Schedule using the Annual work plan of Regional Work unit, using the Development Planning Discussion in order to arrange the Regional Annual Work Plan, determining the final draft of Regional Work Plan based on the result of the discussion, and determining the Regional Work Plan through the Local regulation.

Meanwhile, the budgeting process refers to the Domestic Ministry Regulation Number 13 of 2006 regarding the Regional Finance Management Manual. The processes contain some activities, such as: (1) The regional government delivers the general policy of Regional Budget the following year as a manual to arrange the regional budget. (2) Regional Assembly then discusses the general policy delivered by the regional government in the regional budget planning for the following budgeting year. (3) Based on the general policy of RB accepted by the RPR, the regional government and RPR discussed the Temporary Priority Budgeting Standard (TPBS) as the reference for every RWU. (4) the head of RWU as the budget user should arrange the following year WKP-RWU ( Work Budgeting Planning Regional Working Unit), considering the prescript temporary priority by the RPR. (5) The WBP-RWU then distributed to the RPR to be discussed in the preface of RBP (Regional Budget Planning). (6) The discussion result of WBPRWU is distributed to the regional finance manager as the material to make the regional regulation of the next Regional Budget. (7) The Regional government proposes a regulation program to the RPR in the first week of October of the last year. And (8) the decision-making by RPR regarding the regulation program of RB should be conducted one month before the budgeting year occurs in the latest.

\section{Document of Regional Planning and Budgeting Result}

According to Anggarini and Puranto (2010: 59-60), there was some result that should be produced in regional development planning process, namely: (1) Long-Term Regional Development Planning or LTRDP is a document for 20 years planning period. (2) Medium Term Regional Development Planning or MTRDP is the document for 5 years planning period. (3) Medium Term Development Regional Working Unit or MTD-RWU is a regional document planning for 5 years period. 
(4) Annual Regional Development Planning or Regional Government Work Plan (RGWP) is documenting planning for one year period. (5) Annual Development Planning Regional Working Unit (ADP-RWU) is documenting planning of Regional Working Unit for one year period.

Meanwhile, in the budgeting process, the document that should be produced according to Law Number 17 of 2003 and Domestic Government Regulation Number 13 of 2006 consisting of (1) GBP, is the target and regional policy accepted in one budgeting year as the instruction and general provision in composing the RBU manual. GBP is the document made as the manual in order to arrange the Regional Budget. GBP is composed based on the accepted RWUP. (2) TPBS is a temporary budgeting which is a dynamic process in decision making that is considered most important and is the highest rupiah limit that can be used in each function and RWU. (3) WBP-RWU is the budgeting activity and planning of regional working unit officials. (4) RBU is the regional budget that will be made as Regional Budget by the Regional Government with the agreement of the RPR. (5) RB is the regional budget consisting three main components, namely Regional Income, Regional Expense, and Regional defrayal.

\section{Regional Planning and Budgeting Actors}

In the definition of development planning presented by GTZ (Gesellschaftfür Technische Zusammenarbeit) and USAID-Clean Urban Project in Ashari (2015: 27-28) was explained that development planning is a systematic thing for various actors, either public, private, or other society groups in various level to face the inter-dependence of physical aspects, social-economic, and other environmental aspects by; (a) continuously analyzing the development condition and policy at regional level; (b) Formulating the purposes and policies of development; (c) composing strategic concepts for problem solving (solution), and (d) applying using the source of problem so that new opportunities to increase society prosperity can be obtained and carried on.

That definition means that planning and budgeting process at regional level involve the actors that interact in different levels to face the inter-dependence physical aspects, social-economic, and other environmental aspects by continuously analyzing the development condition and policy at regional level systematically to increase the society prosperity. Based on the definition, all of the stages of planning and budgeting process should involve a variety of actors from the bureaucracy, society, and private so that the resources can be used and the purpose of development can be reached. According to Syaifullah (2008: 29), actors involved are Elected Official (Regional leader and RPR), Appointed office (Bureaucracy) and Society.

\section{Application of Transparency Principle in Planning and Budgeting}

In the process of planning and budgeting, it is important for every planner to hold on to the right planning and budgeting principle. One of which is the transparency principle. According to Munir (2002: 108-109), the arrangement of regional budgeting must consider the norm, transparency, and accountability of the budget. This principle is one of the rules of good governance to realize the good, clean, and responsible government. Considering the regional budgeting is one of the performance evaluation tools and government responsibility in prospering the 
society, so the RB should provide clear information about the purpose, target, result, and benefit obtained from every rupiah. Thus, every fund collected and used can be reported.

Moreover, according to Anggraini \& Puratno (2010) in arranging the Budget Based Performance (BBF), it is necessary to consider the principle of budgeting such as the application transparency principle, accountability and the openness of public space to participate and to assure that various accountable function of finance management run well and every decision regarding regional finance is based on the need for society. Furthermore, in article 3 Law Number 17 of 2003 regarding state in Berek et al. (2006: 81) mentioned that National Finance is managed orderly, obedient to the law, efficient, economic, effective, transparent, and responsible while considering justice and properness. It means that every state organizer in planning, governing, utilizing, monitoring, and accountability is obligated to fulfill the element and principle in that article.

The application of transparency principle has a specific purpose. According to Widodo in Jayanti et al. (2014: 302) the purpose of applying transparency principle are (a) giving easier access to the parties having the chance to obtain the information as an instruction to participate and monitor (b) building positive behavior of the stakeholder and avoiding the apriori attitude toward the regional development programs funded by SFA (Specific Fund Allocation) because of the lack of information or hoax, and (c) creating information availability to open new opportunity to support the society to participate in the regional development program.

\section{Indicators of Transparency in Regional Planning and Budgeting}

Considering regional planning and budgeting process as the arrangement, discussion, and determination of LTRDP, RGWP, GBP, TPBS, WPB RWU and RBU document, so the formulation of indicators should mirror the transparency process and document or the information of regional planning and budgeting. Indicators of transparency in planning and budgeting are formulated by IDASA (Institute for Democracy in South Africa) in Sulistoni and Hendriadi (2004: 158160) cited as follows: (a) the availability of society access to budgeting information, such as openness of budget design (budgeting process), the announcement of budget policy, the documentation of fine budget, the publication of budget result, the documentation of fine budget consisting the fiscal indicators, and the information openness regarding the actual expense. (b) the availability of independent and integrated audit in the budget decision, such as independent and effective audit institution, the availability of statistic office with qualified date, availability of early warning systems in the foul case of execution or budgeting decision. (c) Availability of the society involved in a decision-making process of the budget, such as the openness of information the process of budgeting decision, and availability of chance for civil society to participate in the process of budgeting.

Meanwhile, the other indicators of transparency regional planning and budgeting adopt Kristiansen formula; (a) Availability and accessibility of document, (b) Clarity and Completeness of information, (c) openness process, and (d) regulation design guarantying transparency .(d) this indicator is adopted widely by researcher regarding planning and budgeting in Indonesia. This indicator also referred to the Law Number 14, 2008 about Public Information Openness (PIO 
Law) and The Regulation of commission Information Number 1 of 2010 regarding the standard of Public Information Service. In this study, the indicators above were used to measure the application of transparency principle in planning and budgeting.

\section{METHOD}

This study used qualitative approach emphasizing the development of narrative and descriptive text to the phenomena that will be studied. This is intended to explain the image of various existing data and theories and the discovered findings. This study was conducted in Mataram because it has been planned since 2001 and has received best rank in increasing public information openness information in West Nusa Tenggara Province. The form of this study is descriptive qualitative. Descriptive qualitative form practices phenomenology, a philosophical ideology examining the appearance or phenomena and awareness of unisolating each other but related dialectically. In phenomenological view, something visible must be meaningful for the subject presenting the phenomena, because the phenomena come from the human consciousness hence it must have meaning (Bungin, 2007: 3).

The main instruments for this research was the researcher himself. In this case, the researcher prepared question guide about the main things that should be discovered. In the interview, however, appeared various questions proposed to confirm the answers to the sources. The Instrument used in this study is the voice recorder, camera phone, and field note. This study was conducted in Mataram West Nusa Tenggara. Meanwhile, the object of this study is the true experience of the stakeholder involved in a regional process of planning and budgeting in Mataram. Based on that consideration, the sources chosen for this study are those who are directly involved in process of SCDC planning and budgeting at regional level Mataram. The sourced is chosen using a purposive sampling.

There was three data collection procedure used in this study. Namely, observation, interview, and documental study. Meanwhile, the type of data used in qualitative data from (1) in-depth interview with the sources (primary data) who comprehend the process of planning and budgeting well in Mataram for the last three years and (2) the secondary data obtained from the official government website of Mataram, information from the media, the related research findings, and the data from involved institute the process of planning and budgeting in Mataram.

\section{RESULT AND DISCUSSION}

Based on the study conducted from January to March 2017 in Mataram, 5 clusters of themes are discovered. Namely (1) The openness of SCDC planning and budgeting process, (2) Accessibility and Availability of planning and budgeting information, (3) The Clarity and Completeness in planning and budgeting document, (4) The regulation guarantying transparency and information service institutional, and (5) The perception towards planning and budgeting transparency. These 5 clusters of theme then interpreted by analyzing each cluster. The analysis is strengthened by comparing the concept, theories, and findings discovered by other researchers. The finding and discussion of each cluster as follows: 


\section{The Openness in Planning and Budgeting Process}

The openness or disclosure in planning and budgeting process can be seen from various theme dimensions that have been found during the research, namely:

First, the openness in SCDC planning process. The process and level of SCDC planning have not applied the transparency principle entirely. The application of transparency principle only occurs in the SCDC planning process in sub-district, district, and national level whereas, the village level do not apply the principle of transparency. It is because some village does not apply SCDC process at all. Moreover, the chief of the village initiated the suggestion lists himself and brought them to the application of SCDC planning in sub-district level. The selfinitiated suggestion list appeared undetailed because it does not state the location clearly.

The application of transparency principle also is not applied in information publication regarding the agenda of SCDC planning in a village, sub-districts, and districts level. The organizer distributed only the information about SCDC planning agenda through invitation letters to the previously listed participants, either by the village, sub-district, or district chief. Only in national level is the SCDC planning agenda massive. It can be seen on the billboards and posters displaying the date and time of the event in strategic places.

This variety of condition is not suitable with the Major Regulation Number 35/KPTS/2004 regarding The Application in The Conference of Society Relation that obligates the organizer to announce the schedule, agenda, and location SCDC in all level. In relation to this, Triatmojo (2010) discovers similar things. Namely, the arrangement of RWU planning document by the government is often done without being announced to the public. It means that though the government provides room for the society to participate, the society is often uninvited in the application. The event was not announced to the public. Meanwhile for the LTRDP and RGWP document arrangement is the event that is announced often to the public until it is limited.

The application of transparency principle in the involvement dimension is sufficient; it can be seen from the permission to anyone to attend the SCDC planning process. However, in the last decision making, the facilitator and operator role determine whether or not the suggestions accepted to be discussed in the next stage of SCDC planning. In fact, the facilitator explicitly stated in the forum that if the suggestions from the villagers are unclear, a format is different, and the delegations do not attend, the suggestions will not be accepted and will be deleted from the suggestion lists. These findings are similar to the findings of Equitari and Maryandi (2004) who conducted a research in Bandung. The researchers found that not all of MPKT matched the transparency principle. Moreover, the processes are deemed transparently based on the prescript indicators. Especially in the final decision making.In this dimension of involvement, despite the absence of formal attendance, the invitation delivery is considered limiting the participant presence. According to sources, this was done to avoid additional burden or logical consequence in the form of additional execution cost, especially for the refreshment and the replacement of transportation costs of the participants. On the other hand, there is indeed the humble culture and reluctance in the society when attending SCDC planning without the official invitation especially the society from village level. 
Moreover, based on the observation, it is discovered that government officials and the RPR who attend only gave speeches, opened the ceremony, and distributed little elaboration. Soon after, government officials and the RPR left the SCDC planning forum. Consequently, there is no dialogue between them and the participants. Tough the elaboration given was informative, it appeared that the participant could not comprehend it well. The elaboration given is general and does not describe the strategic issue, policy direction, the budgeting capability, RWU program and event as the discussion references in its process. It is in line with the finding of Syaifullah (2008) who stated that the annual planning (like SCDC planning) is untransparent. Bureaucracy and political staff have more access and authority than other actors. The dialogue is not effective because the information exchange between the bureaucracy and political staff have not distributed the information regarding a strategic issue, policy direction, the budgeting capability, RWU program and event as references in proposing some programs.

Second, socialization and consultation of public document RBU. The application of transparency principle is not done in the form of socialization and consultation of RBU public document. RBU like the common regional regulation draft should be socialized to the society before being delivered to the RPR. The same thing applied before determining it, it should be distributed to the public in order to give suggestions. However, all sources stated that socialization and consultation to the public were not done. There are many reasons causing the process unexecuted, according to sources because of the thick RBU document and limited time. Moreover, some think that the document in under revision or unfinal thus cannot be socialized because of some consideration and over anxiety, such as the emergence of various interpretation.

Some sources think that the application of transparency principle in this stage should be done after RBU is decided and become the Regional budget then distributed via mass media and official website in the form of budgeting publication. the RPR thinks that the application of transparency principle in this process was done by renting pages (advertorial) in news form for budgeting process in local mass media. Outside of that, according to RPR the socialization and consultation of RBU are the obligations of the government that it is not necessary for the RPR to do it. This condition is not suitable for the provisions of article 103 clause 3 Domestic Regulation Number 13 of 2006. The region stated that the design of RB should be socialized to the society before delivered to the RPR. The socialization is an information to the regarding rights and obligation of regional government in RB application in the planned budgeting year.

The unsocialized RBU is feared to impact the lack of RPR in monitoring regional finance and public policy. This is similar to the finding of Setyawati (2010) who stated the knowledge of council members of finance monitoring was not strengthened by the availability of public policy that can increase transparency. Transparency policy is indeed accommodating and increasing the public suggestions. As the public policy, the public access of RBU should be easier. It can be done by providing fast and easy information access. The government should socialize or announce the RBU to the society. IDASA (in Sulistoni and Hendriadi, 2004) mentioned that one of the indicators of transparency is the availability of budgeting information access for the society. Namely, in the form of openness in 
designing budget (budgeting process) and the announcement of every budgeting policy and the publication of budgeting result report.

Third, openness in the budgeting process. The application transparency principle in a budgeting process is never been done entirely. It is seen from the lack of publication regarding the arrangement, discussion, and determination of budgeting document. The information publication regarding this agenda is done by sending an invitation to limited people. In fact, in the discussion of budgeting RPR especially the discussion of budgeting in Budgeting Agency and Joined Commission Meeting tend to be close off. The secured process aroused some negative assumptions that there something sensitive is being discussed. Moreover, it is also seen as the council member interest only, such as the increasing income of RPR and subsidy. Namely, the housing subsidy that should be secured for the sake of RPR positive image in public. Based on the experience in Budgeting Agency meeting, the final decision, budgeting standard, volume and location of a project can be accepted.

In addition to the problem above, the dynamic occurs in the process of budgeting discussion that is not published. This is due to the anxiety that biased information emerged in the society. Without the permission of RPR, anybody cannot join the process. Nevertheless, the budgeting discussion in commission level is open enough. However, the budgeting decree process in the plenary RPR is conducted openly through the society participation is not yet accommodated in this forum. In other words, the access of this forum is limited through the participation is open. In fact, some sources assumed that forum discussion involving society is done at the planning level. In budgeting process, a number of sources stated that society involvement is represented by RPR to discussed GBP, TPBS, WPB and RBU with TAPD. The only journalist with a personal work-related job can join the budgeting discussion in RPR. Not every journalist can join. This group can only join in the commission meeting and plenary meeting.

This study also discovered the keyword in the statement of sources who stated that the process of budgeting discussion is open to the public. However, other sources said that they cannot join the discussion though it is said to be open to public. The head of RPR fears that if the journalist or anyone is allowed to join, the information or news will be biased.Only the final result is distributed to the journalists. This Study also discovered some error perception in RPR, that the society did not attend because of economic problem, According to them, society chooses to earn more money than joining the discussion of budgeting in. Another reason is the fear of different understanding level causing the society participation should be limited. Triatmojo (2010) stated that regional government tends to open the participation access in the planning process, not budgeting process. The participation space for society is commonly provided by the regional government in the arrangement of development planning documents such as LTRDP, RGWP, Strategic planning of RWU and Renja RWU. However, in the arrangement of budgeting document, the involvement of society is unavailable.

Fourth, the publication mechanism in the process of planning and budgeting. The application of related transparency principle is not applied completely. The planning mechanism is decided and distributed in the forum. But the written mechanism is never been distributed to the involved stakeholder. The observation result in SCDC process found that the facilitators give oral elaboration 
only and present the suggestion format to be discussed in the forum. There is no mechanism made in written form to be distributed to the participants. in other words, the application of transparency principle regarding the application mechanism of SCDC planning given only in oral elaboration about the rule, process, and form of suggestions. There is no written mechanism in the form of technical and application manual. It obviously makes it hard for the participants to share and discuss the suggestion. Nevertheless, the organizer has provided the suggestion form that was considered helpful in formulating the proposed suggestion. The same case occurs in the budgeting process. The application of transparency principle is not applied completely. Even though there is a written mechanism, the society cannot join the process. So generally, the mechanism is not really transparent. The chief of the meeting in RPR only orally delivered that the forum is open for public. The nonexistence of technical mechanism regarding the application of transparency principle and involvement of society in the discussion of budgeting is the cause of the assumption that the process is untransparent.

This is not yet matched the indicators formulated by IDASA that to assess the level of transparency, this institution argued that some indicators should present, one of which is Availability of the society involvement in decision making in process of budget, such as (a) the openness of information the process of budgeting decision, and (b) availability of chance for civil society to participate in the process of budgeting. (IDASA in Sulistoni and Hendriadi, 2004). This study discovered that accountability and transparency budgeting in GBP and TPBS RB, Blitar is still unsatisfactory. This is because, First, society is not involved in the process of GBP, TPBS and RRB discussion. Second, the result of the agreement is not distributed to the public both in GBP-TPBS and RBU. Third, the response process is not published. The execution of information published in planning and budgeting has been done via electronic. However, the application is still half done, the government does not publish the result of the discussion.

\section{Document Accessibility and Availability}

Document accessibility and availability information is something that can be used as the important standard in the discussion of transparency. This study discovered the various thematic dimension of accessibility and availability of planning and budgeting document. The dimension is related to the accessibility and availability of LTRDP, strategic planning RWU, the report of SCDC planning result, RGWP, GBP, TPBS, and RBU. Some of the theme found are the following:

First, the access to planning and budgeting document. The application of transparency principle in this dimension is not complete. The research indeed discovered that SCDC planning and budgeting result can be accessed or obtained by oral request. However, the permission is based on the relationship between the applicant and the provider. Like the case of information granting from the of the budgeting discussion result by the RPR to the Non-Government Organization BaKTI Mampu. Furthermore, the planning and budgeting accessed or obtained by applying request letter. This request letter is usually responded in less than 10 days. This occurs with the condition that request letter is the permitted document by the related IDMO and RWU. This is similar to the observation conducted in a number of RWU information services. The planning and budgeting document can also be accessed without making request letter because the document is provided on the 
official website of Mataram Government. However, the complete WPB and RBU are still hard to access. It is because the said document is not provided on the website. In addition, the strength of exception paradigm information in the form of design become one of the caused why the document is hard to access by the public. The nonexistence of IDMO in RWU also potential is deterring the information access to planning and budgeting.

The same case was discovered by Seknas Fitra (2011) who stated that the non-presence of the Institutional Services information tends to perceive the budgeting document request. In some cases, the head of RWU as a public agency did not incline in sharing the document with the excuse of prohibition from the higher authority such as Regional Secretary or the Regional Chief. Nevertheless, there are some heads that were willing to share the documents but the head of RWU rejected the request. This caused different perception to the public. In some region, the appellant should make and propose another request letter of budget information if the previous letter lost. The long process of request letter is why there in no document obtained Sekadau and Bengkayang.

The Government of Probolinggo decline budgeting document request because the Identification Card of the appellant shows that he is not the local inhabitant. Whereas the Law Number 14 of 2008 that obtaining information is the rights of every citizen. It means that the rights are limited by the background of the appellant. A staff in an official in Melawi cannot give the document because the copy is only possessed by the Official Head. In the institutional Information service at the regional government, no case like this found.

However, the finding above is better than the finding Triatmojo (2010) who stated that accessibility and availability of budgeting information are low. All of the budgeting Information is in the state of "Granted by request" with long request time, which is 10 days. It means that to access the information about regional budget about health budget, the society should request it first to the organizer with longtime respond.

Second, the distribution of planning and budgeting document. The application of transparency principle, in this case, is not completely applied. In SCDC planning at village and sub-district level, the document that must be distributed is the suggestion list priority, the previous annual development, the strategic issues that should be examined, information about the number of suggestions obtained that has been realized in the previous year forum, the evaluation result of the annual development realization referring to the article 4, clause (2) in Major Regulation Number 35/KPTS/2004. From the observation and interview, it was found that the document planning distributed by the organizer in SCDC in village level, only problem list pointed as the result of SCDC planning. Meanwhile in SCDC at the sub-district and regional level is the suggestion of priority event according to (Human Resource, Facilities) that has been synchronized with the RWU suggestion. The distributed document then treated as the reference in meeting to repair, strengthen, completing the lack of information provided in eSCDC application. The discussion result decided to be accepted or not accepted in RGWP. However, because the number of documents is limited, there are some participants who do not get it. Whereas in the budgeting process, the detailed information cannot be distributed. Generally, sources said that budgeting 
information document like GBP, TPBS, WPB, and RBU are arranged and discussed between TAPD and RPR.

Third, Document publication. The application of transparency is not applied completely. It is because only certain documents are published either from SCDC information process on the Website of Mataram Government. Generally, the information governance knows the importance of this publication. However, they give limit that the publication can only be done if the document is final. The final result of SCDC such as annual development planning document at a village, subdistrict, and district level is not published widely via mass media or website. However, LTRDP and RGWP document are published via Website. Meanwhile, the publication of budgeting documents such as GBP, TPBS, WPB, and RBU will only be done if they are accepted by RPR. The sources experience shows that the finalized GBP, TPBS and WPB document is published via a website. Meanwhile, the RBU document is published via both mass media and website. Nevertheless, personally, the RPR members said that budgeting information is constituent, either orally or in the document copy. However, from the publication or socialization of RBU document, the members of RPR state that it was the government obligation, in this case, TAPD, not RPR.

Fourth, the document presentation. The application of transparency principle in this part is sufficient. Especially regarding the document planning. However, the presentation of the document is generally conducted in units and fields. There is no initiative in providing the document in one place. Thus, even tough IDMO and information service exist, information planning and budgeting still in RWU or related field. According to one of the sources, the planning and budgeting document commonly submitted to the Regional Development Agency and Regional Finance Agency. Ideally, in the SCDC planning, the document is provided to be distributed as the reference for the participant in discussing and determining the activities and budgeting suggestion, but most not provided. Planning document like the priority suggestion lists at the village, sub-district, district, and regional level, potential and problem data, evaluation result document of the previous year which is available by the Regional Development Agency. Moreover, RGWP document is available on the official website of Mataram Government. The availability of budgeting document of GBP and TPBS is also available in Regional Development Agency. Whereas, the WPB document is available in RWU and RBU in Regional Finance Agency. The presentation of information document is usually intended to make the access easier for the appellant. However, because the information is under the surveillance of the authority units and field, this expectation is hard to be reached. The accepted RBU is available but not to be distributed to the society. This document is only for the sake of budgeting discussion conducted by the TAPD and RPR.

As a comparison, in the Performance report of Regional Budget Management (Seknas Fitra, 2011) stated that information of planning and budgeting include in the category that must be provided and announced periodically. This is stated in Circulated Commission Letter of Central Information Number 1 of 2011 which stated that Work Plan Budget (WPB) and The List of Budgeting Application (LBA) are the information that must be provided and announced by the government. The letter emphasized that WPB and LBA are not confidentially documented to be secured by the government but the society has to know about it. The same report 
shows that many budgeting and planning document found at a regional level to be inaccessible. From the 410 document collected, $45 \%$ or 185 documents are inaccessible. Moreover, $35 \%$ or 143 documents examined by request are not responded by the government. Meanwhile, there are 82 documents or $20 \%$ of documents are collected through access examination.of 82 documents, 73 documents are obtained by request, and the other 9 are obtained without request because the document has been published. The access to planning document is not easier than the access to budgeting document. Of all of the planning documents, only the result of RGWP access examination that is significant (14 regions). This condition is different from the findings in 2009 and 2010 that found the planning documents tend to be easier to obtain than other stages.

All of these dimensions are related to the importance of fulfilling the society rights of information. The rights fulfillment aims to avoid the asymmetrical information between authority or information holder and the society or the information users. Stiglitz (1998) in some literacies had stated the importance of information in the process of policy making. He analogized information as money, assets or other resources. According to him, economic losses in society are caused by asymmetrical information or imperfect information. Even though he saw the existence of information in economic perception, basically, he would like to state it substantially that availability of information is important. If one party (society) does not get the information, this can lead to a loss in the future.

\section{Information Clarity and Completeness Document}

Information clarity and completeness mean that the presented document is easy to comprehend, unbiased, one interpretation, and supported by the suitable data. This study shows that various dimensions related to the application of transparency principle applied well. It can be seen from the findings below:

First, Information clarity and completeness regarding the location of an event. This study discovered that transparency principle application in this dimension is not applied well in the planning and budgeting document arrangement. Some sources expressed that in planning and budgeting document, the information regarding the location of an event is not provided clearly in the document. The suggestion offered does not consider the completeness of supporting data such as picture or location map.

Second, Information clarity and completeness budget. Transparency in this dimension is also not applied well. It is because in some document of planning and budgeting rarely state the detailed budget suggested or offered especially in the SCDC planning and RBU. There was also some source stating that the location name, budget standard, and budget detail are stated in the document. It means in this dimension, transparency is actually applied. Only in planning document of proposed and the plan organizer do not consider the budget need.

Third. the information clarity regarding detailed volume and object. The volume and detailed expense object were written in the suggested document are not considered. Planning document, volume, and object are not detailed or often in the form of raw suggestion. The undetailed volume and expense object cause corruption and the abuse of authority in organizer level. The unclear and incomplete information makes it difficult for the society and government in the monitoring 
process in every budgeting and event. Whereas for common people, it will be difficult to read and understand the content of the document.

Fourth. the clarity of standard information and performance target. In this dimension, almost all of the documents have not supplied the standard and performance target clearly. In budget based performance, standard and performance are certainly to be filled. In document planning such as RGWP, program, and activity indicators are lacking in providing the information clearly especially in the output and result column. Meanwhile, in GBP and TPBS document, information about the program and target is unclear and unrealistic. So is the WPB document, the performance standard, and target have not been elaborated clearly and realistically.

Related to the four dimension regarding the Information clarity and completeness in the documents above, the research done by Triatmojo (2010) in Bandar Lampung inferred different result and measured it quantitatively. In the case of Information clarity and completeness, budgeting is in 65,1 percent. The percentage means the printed documents in healthcare budget will be understood directly by the society regarding the size, aim, reason, performance and use of the budget.

\section{Regulation of Transparency and Institutional Information Service}

The findings show the dimension regarding regulation transparency and institutional information service is applied sufficiently. It is since 2014, the regional government has decided the regulation, formed IDMO, made space for service in the last 2 years and received good evaluation result from the Information commission West Nusa Tenggara Barat Province. In fact, in 2016, the public information was better than the other 9 regions in West Nusa Tenggara (Evaluation Report of Information Commission West Nusa Tenggara 2016). The discussion of this section explains 3 dimensions in the application of transparency principle such as the regulation guarantying transparency, formed and functioning IDMO, and service of information request. Each will be explained below:

First, the regulation guarantying transparency. The application of transparency principle in this dimension is fulfilled and run well. The Government of Mataram guarantees information transparency or information disclosure for the society. It is showed by the publication of Major Regulation in Mataram Number 5, 2014 regarding IDMO. This Manual is a reference for IDMO and society to run their rights and obligation in public information openness. This Regulation refers to the IC Law and PerKI SLIP. Generally, the regulation regarding guarantee of transparency of information openness is considered the most complete in comparison to other regulation because there is a Law and supporting and guarantying transparency in Mataram.

Second, the formation and functioning of Information and Documentation Management Official (IDMO). The application of transparency principle in this dimension is fulfilled by the formation of IDMO, but the function is not yet effective. The government of Mataram formed IDMO in main IDMO level and IDMO RWU. Almost 90 IDMO institutions formed RWU, only some RWU that have not formed IDMO such as Regional Development Agency and Regional Finance Agency. Especially for RFA, sources in IDMO of Mataram confessed that the RFA has been invited repeatedly but has never attended the formation of IDMO. 
Because the RDA and RFA have not formed IDMO, the information service function is done by each field or related RWU. The information service in those institutions is not maximum because of the lack of IDMO formation.

Nevertheless, this condition is better than other regions. The report of Seknas Fitra (2011) showed that not many regional governments from information service institution especially IDMO and SOP regarding information service. This study discovered that there are 4 regional governments pointing IDMO, Bengkayang, North Luwu, Bulukumba, and Singkawang. Whereas the Standard of Operational and Procedure (SOP) regarding information service arranged in Singkawang is the only region having second information service institution. The studied regions in East Java and Aceh have not appointed IDMO until the submission period ended.

Third, information service. This dimension is related to the regulation and IDMO institution. If regulation and IDMO institution are available, usually information service runs well. The information service of planning and budgeting in Mataram was done directly, not via the website (online). The direct information service in the units or IDMO in Mataram has run well. It can be seen from the response or information requests, the types of information supplied and distributed, the publication activities, the availability of information, the information request reports distributed to the Public in West Nusa Tenggara Province. The information response and request are running smoothly despite being a little slow. It is seen from the lack of information requests rejections and the information distributed in less than 10 days. If the information was not available, the applicant is usually led to other RWU bearing the said information. If RGWP, GBP, TPBS were requested, they would be given.

However, the study discovers that there was some RWU information response that was given in more than 10 days. Moreover, the document request for WPB and RBU are still hard to be requested though they were responded. It is because the document is considered the unfinished draft and not yet applied to the official document by the TAPD and RWU. Some IDMO also does not provide information request form and list them in a specific book such as the information request list book.

The same case was discovered by Seknas Fitra (2011) who stated that the presence of different perceptive between government staff in perceiving the budgeting document request. In some cases, the head of RWU as the public agency did not incline in sharing the document with the excuse of prohibition from the higher authority such as Regional Secretary or the Regional Chief. Nevertheless, there are some heads that were willing to share the documents but the head of RWU rejected the request.

\section{The Perception of Budgeting and Planning Transparency}

The sources perception regarding the application of transparency principle in planning and budgeting is varied. It can be seen from the variety of sources' essence meaning of transparency, benefit, and impact, their expectation, and assessment towards the condition of applicating transparency principle in planning and budgeting in Mataram. This perception is form based on the sources' experience while participating in various level of planning and budgeting and the period of time joining the process. Specifically, it will be explained in the following: 
First, defining transparency and its application. This study shows the variety of understanding of the sources' regarding the meaning of transparency and its application in planning and budgeting. Some of the sources defined transparency as publication activities and assurance that the information reaches the society. Other sources described that transparency should not necessarily be fully open, transparency as the two-way information and can be tested, transparency also include other people's rights that should be given, and transparency is about the clarity of activities and fund sources, and involving many parties in the process. However, the variety of the problem leads to one similar essence which information openness is related to the planning and budgeting and the resulted document.

Stiglitz (1998); Zetra (2009) gave a more systematic explanation about the definition of transparency. According to Stiglitz (1998), Transparency is basic rights to know the information about the ongoing program by the government and why was it chosen to be funded. In principal-agent context, the citizen as principal has the right to understand the behavior of their agent especially when the agent is the government or international organization. This argumentation is in Line with Krina (2013) who stated that transparency is a principle or value guarantying the access or freedom for everyone to obtain information about administration organization.

Second, the benefit and effect of transparency principle. This study also discovered various sources' statement regarding the benefit and effect of transparency principle in planning and budgeting. Most of the source stated that the application of transparency principle in planning and budgeting will be beneficial and will affect lower corruption and better public service. However, the application of transparency principle is very beneficial to erase suspicion, avoid untrusted program and overlapping budgeting. The application of transparency principle can also motivate public participation in planning and budgeting process and increased the application accountability in the public's eyes. In cases above, some of which were in line with what was stated by Triatmojo (2010) who argued that the availability factor of budgeting document and the clarity and adequacy of budgeting information is indeed better but the factor of document accessibility and the information availability of budgeting information are still unsatisfactory. Those conditions are more or less integrated and affecting the quality of public participation. According to Triatmojo (2010), there are at least three obstacle in public participation in the budgeting process because the low budgeting transparency, such as; a) the difficulty of obtaining information about open meetings that can be joined by the society; b) the unclear criteria taken by the regional government in choosing the worthed society delegations to be invited to the meeting; c) the difficulty to access the public document and to obtain both the Law document related to the budgeting and health care rights and the participation of society.

Whereas Zetra (2009) emphasized that the presence of transparency and accountability in government financial management makes the government (Central or regional) get the public trust and support. Eventually, the government will be more serious and more discipline in working the application of budget will be more participative and pro-poor, the mechanism of monitoring internally and externally will be stronger that we can be free from corruption, collusion, and nepotism. Furthermore, with the increasing of financial transparency and 
accountability, it is expected that the public service will be better and the good governance and clean government will turn to reality.

Third, expectation regarding the application of transparency principle. This study found that various sources' statement regarding the application of transparency principle in planning and budgeting. One of which is the desire for more concrete detail of planning and budgeting and every job is done as planned. The government should form more forums to socialize the planning and budgeting. Moreover, the budgeting realization must be in agreement with public suggestions in SCDC planning

Fourth, the assessment of the transparency principle. There is a variety of assessments for the application of transparency principle in planning and budgeting. It was influenced by the intensity of involvement and experience of each source. On average, the sources gave sufficient assessment toward the transparency principle (80\%). However, some sources gave a low assessment for the application of transparency principle in budgeting (50\%). This is because there is no society involvement, no socialization and public consultation of Regional Budget Planning, the lack of publication of discussion result and the low information service. Like the finding of Ashari (2015) who stated that the society still considered the Regional Budget cannot mirror the needs of the society and is not suitable for the result of Development Planning Conference. It was because the lack of information obtained by the society from the government regarding the budgeting.

\section{CONCLUSION}

Based on the research findings and discussion, it can be concluded that the planning in Mataram has applied transparency, yet to do done maximally, while the budgeting in Mataram has not completely applied transparency. Both similar conditions happen because of several things, such as; (1) planning and budgeting process is not distributed widely, the application includes only the predetermined group of society, the activity and attendance mechanism only distributed by invitation. Some SCDC planning in a local area is not executed. (2) Accessibility and availability of information are limited, this is caused by the majority of information can only be obtained by proposing application letter. An oral request is given because of friendship or the close relationship between the information petitioner and the granter. Moreover, the planning and budgeting information does not provide one specific area of the Information and Document Management Officials or Information room. (3) The clarity and adequacy of the information given in the document it not yet suitable. This occurs because the un-detail information displayed unclear location, budgeting, and target performance. This condition makes it hard for the society to do monitoring and to assure the readiness of participation and development application. (4) The regulation that guarantees transparency and institution of the information service has been composed, but the implementation does not run well in the Development Planning Agency in SubNational Level and BKD. It is because not all of the document can be accessed quickly, the time of service information still more than 10 work days, the IDMO also does not provide request forms and does not register requests. (5) Most of the information has sufficient perception of the principle of transparency in planning by giving high assessment scores. It is because most process and steps of the application are opened and the access to the information is easier to obtain. 
However, the perception towards transparency in budgeting is still low either from low scores for budgeting, accessibility, and availability of information as well. Nevertheless, most of the source expects that the planning and budgeting process will be better in the future by increasing the transparency process, strengthen information access by multiplying socialization forums or the information publication regarding planning and budgeting, as well as the agreement between planning result with the realization.

Based on the research finding and discussion, a recommendation can be given in order to increase the quality process and result of the regional planning and budgeting. The intended recommendation is in the form of technical recommendation, policy, and recommendation for future research, as the following (a) Technical recommendation; The Government of Mataram especially Development Planning Agency at Sub-National Level should (1) give technical guidance intensively to the SCDC as the key actor whether or not the planning process is done transparently. (2) intensify the publication process and SCDC planning and budgeting result using mass-media or website that can reach public widely, (3) give warning to the local leader who does not apply SCDC, and (4) provide the materials needed in the SCDC planning and budgeting process to be distributed to public earlier (three days before the execution). (b) Policy Recommendation; the government of Mataram should (1) make application manual and technical manual about planning and budgeting in a form of the pocketbook to be distributed to the participant as an instruction in the planning and budgeting process. (2) Make rules regarding the use of e-SCDC application and e-budgeting so that the publication result and process of planning and budgeting become wider and the continuance is guaranteed. (3) Give written the warning to the head of Regional Working Unit who have not formed Information and Documentation Management Officials and Standard Operational Procedure of information service in each Regional Working Unit.(c) Recommendation for Future Researcher; The findings of this study can be used as a reference to conduct future research quantitatively or qualitatively. The research recommended for a future researcher is a topic like the experience of stakeholder in the application of e SCDC in Mataram and the study of the phenomenological experience of stakeholders regarding budgeting information openness in Mataram.

\section{REFERENCES}

Anggarini, Y., \& B. H. Puranto (2010). Anggaran Berbasis Kinerja: Penyusunan APBD Secara Komprehensif. Yogyakarta: Sekolah Tinggi Ilmu Manajemen YPKN.

Ashari, M. (2015). Analisis Perencanaan Pembangunan Daerah di Kabupaten Lombok Utara (Studi Kasus Perencanaan Partisipatif Tahun 2009 -2013). Tesis Magister Ilmu Ekonomi Universitas Mataram, Mataram-Indonesia.

Berek, P. D., Haryadi, J. E., Sulistiana, S., Fatimah., \& D. Satriana. (2006). Kumpulan Modul Pendidikan Politik Anggaran Bagi Warga. Bandung: Bandung Institute of Governance Studies.

Bungin, B. (2007). Penelitian Kualitatif untuk Komunikasi, Ekonomi, Kebijakan Publik dan Ilmu Sosial Lainnya, Jakarta, Kencana Prenada Media Group.

Conyers, D., \& Hills, P. (1984). Introduction to Development Planning in the Third World. 
Equitari, K. E., \& Maryandi. (2004). Transparansi dan Akuntabilitas dalam Proses Musyawarah Perencanaan Kegiatan Tahunan (MPKT) di Kabupaten Bandung Tahun 2003. Jurnal Perencanaan Wilayah dan Kota, 15(1), 69-90.

Indarto, M. J. (2012). Manajemen Komunikasi Pemerintah dalam Kebijakan

Transparansi Informasi (Studi Evaluasi Keterbukaan Informasi Publik pada

Kementrian Komunikasi dan Informatika). Tesis Magister Universitas Indonesia, Jakarta.

Jayanti, I. P., S. Syamsudin., \& A. Wachid. (2014). Reformasi Pengelolaan Keuangan Daerah dalam Rangka Mewujudkan Transparansi dan Akuntabilitas (Studi pada Pemerintah Kota Malang). Jurnal Administrasi Publik, 2(2), 300-305.

Jhingan, M. L. (2013). Ekonomi Pembangunan dan Perencanaan. Jakarta: Rajawali Press.

Jumarim. (2007). Membedah Jantung Negara: Buku Pegangan Dakwah Anggaran Mustadl'afien, Mataram, Dewan Peduli Anggaran NTB.

Kinerja Pengelolaan Anggaran Daerah (KIPAD) Hasil Penelitian di 20 Kabupaten/Kota Program KINERJA, SEKNAS FITRA. Jakarta: The Asia Foundation.

Kinerja Pengelolaan Anggaran Daerah (KIPAD), SEKNAS FITRA. Jakarta: The Asia Foundation.

Krina, L. L. P. (2003). Indikator dan Alat Ukur Prinsip Akuntabilitas, Transparansi dan Partisipasi. Jakarta: Sekretariat Good Public Governance Badan Perencanaan Pembangunan Nasional.

Maani, K. D. (2009). Transparansi dan Akuntabilitas dalam Pelayanan Publik. Jurnal Demokrasi, 8(1), 1-14.

Martani, D., Fitriasari, D., \& Annisa, (2013). Transparansi Keuangan dan Kinerja pada Website Pemerintah Daerah Kabupaten/Kota di Indonesia. Proceeding PESAT, Vol. 5.

Munir, B. (2002). Perencanaan dan Pembangunan Daerah dalam Perspektif Otonomi Daerah. Mataram: Bappeda Provinsi NTB.

Patchurrahman, B., Untung, A. Rofik., Wawanudin, M. Fahazza., \& Raharjo, B. (2013). Modul Penguatan Kapasitas Masyarakat dalam Mengakses Informasi. Jakarta: Pusat Telaah dan Informasi Regional.

Peraturan Daerah Kota Mataram Nomor 27 Tahun 2001 Tentang Musyawarah Pembangunan Bermitra Masyarakat. Mataram: Bappeda Kota Mataram.

Peraturan Komisi Informasi Nomor 1 Tahun 2010 Tentang Standar Layanan Informasi Publik. Jakarta: Komisi Informasi Pusat.

Peraturan Menteri Dalam Negeri Nomor 13 Tahun 2006 Tentang Pedoman Pengelolaan Keuangan Daerah sebagaimana telah diubah dengan Peraturan Menteri Dalam Negeri Nomor 59 Tahun 2007 Tentang Perubahan atas Peraturan Menteri Dalam Negeri Nomor 13 Tahun 2006 Tentang Pedoman Pengelolaan Keuangan Daerah. Jakarta: Kementerian Dalam Negeri.

Pope, J. (2003). Strategi Memberantas Korupsi: Elemen Sistem Integritas Nasional. Jakarta: Yayasan Obor Indonesia.

Sa'adah, B. (2015). Akuntabilitas dan Transparansi Anggaran Melalui EGovernment (Studi Tentang Penganggaran di Pemerintahan Daerah Kabupaten Blitar). Jurnal Kebijakan dan Manajemen Publik, 3(2), 1-10.

Setyawati, Y. (2010). Pengaruh Pengetahuan Anggaran Anggota Dewan Terhadap 
Pengawasan Keuangan Daerah (APBD) dengan Partisipasi Masyarakat dan Transparansi Kebijakan Publik Sebagai Variabel Pemoderasi (studi Empiris di Keresidenan Surakarta). Tesis Magister Akuntansi Universitas Sebelas Maret, Surakarta.

Sopanah. (2014). Ceremonial Budgeting dalam Perencanaan Penganggaran Daerah: Sebuah Keindahan yang Menipu. Naskah Publikasi Widyagama Malang retrieved from http://www.asp.trunojoyo.ac.id/wp-content/uploads /2014/03/056.

Stiglitz, J. (1998). Redefining the Role of the State: What Should It Do? How Should It Do It? And How Should These Decisions be Made?. Retrieved from http://people.ds.cam.ac.uk/mb65/library/stiglitz-1998.pdf.

Sulistoni, G., \& Hendriadi. (2004). Anggaran Tak Sampai, Mataram, Solidaritas Masyarakat untuk Transparansi.

Syaifullah. (2008). Analisis Perencanaan Pembangunan Tahunan Daerah di Kota Magelang (Studi Kasus Perencanaan Pembangunan Tahun 2007). Tesis Magister Ilmu Administrasi Universitas Diponegoro, Semarang.

Syarifudin. (2003). Model-Model Anggaran Pada Organisasi Sektor Publik, Makalah dipresentasikan pada seminar bulanan Jurusan Akuntansi Fakultas Ekonomi Universitas Hasanudin, Makasar.

Triatmojo, F. (2010). Transparansi Anggaran Sektor Kesehatan Daerah. Jurnal Ilmiah Ilmu Administrasi dan Pembangunan, 1(2), 161-172.

Undang-Undang Nomor 14 Tahun 2008 Tentang Keterbukaan Informasi Publik (Lembaran Negara Republik Indonesia Nomor 61 Tahun 2008).

Undang-Undang Nomor 17 Tahun 2003 Tentang Keuangan Negara (Lembaran Negara Republik Indonesia Nomor 47 Tahun 2003).

Undang-Undang Nomor 25 Tahun 2004 Tentang Sistem Perencanaan Pembangunan Nasional (Lembaran Negara Republik Indonesia Tahun 2004 Nomor 104).

Zetra, A. (2016). Strategi Pengembangan Kapasitas SDM Pemerintah Daerah dalam Mewujudkan Transparansi dan Akuntabilitas Pengelolaan Keuangan Daerah. Naskah Publikasi, Retrieved from http:/www.bpk.go.id/assets/ files/ attachments/2009/270609. 